\title{
Profile of Antimicrobial Resistance of Bacteria Isolated from Cockroaches (Periplaneta americana) in a Brazilian Health Care Institution
}

\author{
Marinésia Aparecida Prado ${ }^{1}$, Elucir Gir ${ }^{2}$, \\ Milca Severino Pereira ${ }^{1}$, Cleomenes Reis ${ }^{1}$ \\ and Fabiana Cristina Pimenta ${ }^{1}$
}

\author{
${ }^{1}$ Federal University of Goiás, Goiânia, GO; ${ }^{2}$ São Paulo University, \\ Ribeirão Preto, SP; Brazil
}

\begin{abstract}
Cockroaches carry microorganisms to sterilized materials, equipment and non-contaminated food in hospitals and in homes. Hence, they are regarded as major microbial vectors. We isolated and identified microorganisms from living cockroaches captured from a Brazilian health care institution and we determined the antimicrobial susceptibility profile of the isolates. Following collection, cockroaches were immobilized at $4^{\circ} \mathrm{C}$ for 10 to 20 minutes, immersed in $0.8 \%$ saline solution and then homogenized. Next, the suspension was seeded in culture media: brain and heart agar infusion, MacConkey agar, Naito agar, and they were incubated for up to 48 hours at $37^{\circ} \mathrm{C}$. Sabouraud agar cultures were incubated at ambient temperature. The microbial colonies were analyzed with a stereomicroscope to count and phenotypically identify the colony-forming units (cfu). The discdiffusion method was used to determine the profile of susceptibility to antimicrobials. Among the 103 cockroaches analyzed, fungi were found in $97 \%$, enterobacteria in $\mathbf{7 4 . 6 \%}$ and coagulase-negative staphylococci (CNS) in $\mathbf{2 5 . 4 0 \%}$. Among the enterobacteria, $96 \%$ were resistant to gentamicin, $84 \%$ to ampicillin, $75.3 \%$ to caphalothin, $66.7 \%$ to ampicillin-sulbactam, $50 \%$ to aztreonam and $30 \%$ to chloramphenicol. Among the CNS, $61 \%$ were resistant to oxacillin. We concluded that cockroaches carry organisms associated with nosocomial infections and that are resistant to antimicrobials. This fact contributes to the epidemiological chain, complicating therapeutics, and consequently, medical costs are increased.
\end{abstract}

Key Words: Cockroach, microorganism, nosocomial infection, antimicrobial resistance.

Cockroaches carry germs. Voracious, destructive and offensive, they have nocturnal habits, live in sewage pipes, latrines, garbage, wall slits, baseboards and filthy places. There are many species of sanitary importance and one of major importance is Periplaneta americana [1-5].

These insects are found in different hospital sectors, as they are attracted by food, organic waste and fluids that are regularly discharged in such sites [2,5]. Wastes are attractive to insects, particularly to ants and cockroaches, which are mechanical carriers of virulent microorganisms that are associated with nosocomial infections and that have shown to be resistant to antimicrobials [2,5].

Cockroaches may nibble at the lips and the angular region of the mouth of unconscious or sleeping bedridden individuals, particularly children when they regurgitate milk. This causes a lesion on the site that is known as herpes blattae $[6,7]$.

Nosocomial infection, which is also referred to as institutional or hospital infection, is that which is acquired after the client's admission in the hospital and is manifested during his stay there or after discharge in case it is related to

Received on 10 October 2005; revised 07 February 2006. Address for correspondence: Dr. Marinésia Aparecida. Rua Dr. Adolfo Pamplona, 138, Zip code: 14021-320, Ribeirão Preto, São Paulo, Brazil.E-mail: marinesiaprado@terra.com.br

The Brazilian Journal of Infectious Diseases 2006;10(1):26-32. (C) 2006 by The Brazilian Journal of Infectious Diseases and Contexto Publishing. All rights reserved. hospitalization or hospital procedures [8]. During the last two decades, studies developed with cockroaches captured from nosocomial environments have shown the presence of microorganisms lodged on their surfaces, such as Enterobacter sp., Klebsiella pneumoniae, and Staphylococus aureus [9,5]. Cockroaches are usually major carriers of disease organisms; they play a supplementary role in dispersing the etiological agents of infections, such as diarrhea, dysentery, cholera, tuberculosis, and typhoid fever $[2,10]$.

The introduction of antimicrobials in the therapeutics of infectious diseases was described over 2,500 years ago. At that time, they were regarded as the solution to all diseases caused by microorganisms $[11,12]$. However, their widespread and indiscriminate use has caused the selection of resistant strains, and their empirical use, the lack of institutional standardization policies and pre-established criteria for their acquisition or therapeutic prescription, among other factors, have led to a selective pressure on microorganisms, leading to difficult to treat, multiresistant strains. This has created impasses in the clinical treatment of patients, especially in health-care institutions [11-14].

\section{Material and Methods}

Cockroaches were collected from a large health care institution in Brazil that has 365 beds, general and hematooncological outpatient clinics, as well as emergency, support and therapeutic services. The insects were collected from five different units: supply rooms for the surgery room, two infirmaries, a coffee shop and the nutrition and dietetics 
services. The cockroaches were captured during three consecutive weeks in March 2002, twice a week, in the morning and at night. They were placed in bottles whose bases had been removed and whose lids had been adapted. The bottles had been previously decontaminated using water and soap. They had also been dried and disinfected with $70 \%$ alcohol and rubbed with sterilized dressing. Next, the animals were transferred to a sterilized glass bottle and transported alive to the laboratory.

One hundred and three living whole cockroaches were selected and immobilized at a temperature of $0^{\circ} \mathrm{C}$ for 5 to 20 minutes. They were then separately removed from the bottle using anatomical tweezers. Next, they were measured with a millimetric ruler, and then transferred to a test tube containing $0.5 \mathrm{~mL}$ of $0.8 \%$ sterilized saline suspension. The insects were rigorously homogenized for two minutes [15].

The saline suspension was transferred to another test tube and decimal dilutions up to 105 were made; 0.25 -mL aliquots were dripped onto Petri dish surfaces containing the following culture media: Naito agar, manitol agar, MacConkey agar, brain and heart infusion agar (BHI) and Sabouraud agar [16].

The Petri dishes were incubated at $370 \mathrm{C}$ for 24 to 48 hours. The colonies were examined with a stereomicroscope in order to count the colony-forming units (cfu), and they were biochemically identified. The Gram-negative bacteria were submitted to tests such as indol tests, motility, methyl red, hydrogen sulfide production, growth in Simomons citrate, fermentation of glucose, lactose, saccharose and manitol, and urease and phenylalanine decarboxylase production [17]. The colonies with a Gram-positive coccus morphology isolated in Naito agar and in BHI Agar were submitted to catalase, coagulase and lecitinase production tests [17]. The Petri dishes containing Sabouraud agar were incubated at ambient temperature for seven days, after which time the colonies were counted and classified as yeasts or filamentous fungi.

After the Gram-negative bacilli and Gram-positive cocci had been identified, they were submitted to an antibiogram using the disc diffusion method, according to NCCLS recommendations for the determination of antimicrobial susceptibility [18]. The strains were seeded in simple inclined agar slants and incubated at $370 \mathrm{C}$ for 24 hours. The bacterial inoculates were prepared in $0.8 \%$ saline solution at a concentration that was half scale 1 proposed by MacFarland. The inoculates were seeded in Muller Hinton agar, the discs were distributed in an equidistant fashion and the plates were incubated at a temperature of $37^{\circ} \mathrm{C}$, for 24 hours. The reading was performed by measuring the halos and comparing with the tables developed by NCCLS.

The Gram-negative bacilli were submitted to antibiotics (CECOM): ampicillin ( $10 \mathrm{mcg})$, caphalothin $(30 \mathrm{mcg})$, ceftriaxon (30 mcg), chloramphenicol (30 mcg), gentamicin $(10 \mathrm{mcg})$, sulfazotrin (250 mcg), cefepime (30 mcg), aztreonam (30 mcg), ampicillin-sulbactam (30 mcg), ciprofloxacin ( $5 \mathrm{mcg})$ and the
Staphylococci were submitted to the following agents: cefalexin (30 mcg), vancomycin (30 mcg), ampicillin (10 mcg), cefepime (30 mcg) and oxacillin (1 mcg).

The statistical analysis was performed by the Epi-Info, v.6.0 program, developed by the CDC (2000).

\section{Results and Discussion}

One hundred and three Periplaneta americana cockroaches were collected in five different units of a large healthcare institution in Brazil. Among these, 91 gave microbial growth, from which 126 isolates were obtained; $71.4 \%$ had species in the Enterobacteriaceae family, $25.4 \%$ were coagulase-negative staphylococci and $3.2 \%$ were Gramnegative bacilli. Filamentous fungi and yeasts were also detected in $97 \%$ of the cockroaches, and the mean number of types of microorganisms isolated per cockroach varied from one to three.

The number of colony-forming units (cfu) found in each cockroach in the enterobacteria group ranged from 10 to $200,000 \mathrm{cfu} / \mathrm{cockroach}$, and the median and mode for this group were $100,000 \mathrm{cfu} / \mathrm{cockroach}$ (Table 1).

Table 1. Frequency distribution (F) among cockroaches and percent of the number of colony-forming units (cfu) of enterobacteria isolated from Periplaneta americana in a large public hospital. In Goiânia, Brazil in 2002

\begin{tabular}{lrr}
\hline Colony-forming units & F & $\%$ \\
\hline $10-\mid 10,000$ & 54 & 59 \\
$10,000 \mid-20,000$ & 9 & 10 \\
$20,000 \mid-30,000$ & 7 & 8 \\
$30,000 \mid-40,000$ & 5 & 5 \\
$40,000 \mid-50,000$ & 7 & 8 \\
$50,000 \mid-60,000$ & 0 & 0 \\
$60,000 \mid-70,000$ & 1 & 1 \\
$70,000 \mid-80,000$ & 0 & 0 \\
$80,000 \mid-90,000$ & 0 & 0 \\
$90,000 \mid-100,000$ & 6 & 6 \\
$100,000 \mid-200,000$ & 3 & 3 \\
Total* & 92 & 100 \\
\hline T* detection of growth in different colonies from \\
the same cockroach; F=frequency.
\end{tabular}

When enterobacteria contamination was compared, 59\% of the cockroaches carried from 10 to $10,000 \mathrm{cfu} ; 10 \%$ carried $20,000 \mathrm{cfu} ; 8 \%$ from 30,000 to 50,000 cfu and $6.5 \%$ from 90,000 to $100,000 \mathrm{cfu} / \mathrm{cockroach}$. These results confirm that cockroaches disseminate infectious microorganisms in hospitals, since they harbor a significant number of microorganisms.

For most microorganisms, the infective dose (number of cfu), which is capable of inducing infection in people at home or in nosocomial environments, has not yet been well 
established [19], since various factors are involved in the development of nosocomial infection. However, it is known that the higher the concentration of cfu, the greater the risk of contamination and infection.

Among the coagulase-negative staphylococci, cfu counts ranged from 20 to 56,000/cockroach; the median was 41,500 and the mode was 3,000 cfu (Table 2).

Table 2. Distribution of frequency of colony-forming units of coagulase-negative staphylococci isolated from Periplaneta americana at a large public hospital In Goiânia, Brazil in 2002

\begin{tabular}{lrr}
\hline Colony-forming units & F & \% \\
\hline 20 & 3 & 9.4 \\
120 & 1 & 3.1 \\
200 & 2 & 6.2 \\
260 & 3 & 9.4 \\
1,280 & 1 & 3.1 \\
2,000 & 14 & 44.0 \\
7,800 & 2 & 6.2 \\
20,000 & 4 & 12.5 \\
38,000 & 1 & 3.1 \\
56,000 & 1 & 3.1 \\
Total & 32 & 100 \\
\hline
\end{tabular}

$\mathrm{F}=$ frequency.

Among the 103 cockroaches collected from the hospital that yielded microbes, 100 were contaminated with fungi classified as: filamentous; filamentous and yeasts, and yeasts (Table 3).

Table 3. Distribution of the classification of fungi isolated from cockroaches (Periplaneta americana), captured from a large hospital In Goiânia, Brazil in 2002

\begin{tabular}{lrr}
\hline Fungi classification & F & \% \\
\hline Filamentous & 60 & 58.2 \\
Yeast & 29 & 28.2 \\
Yeast and Filamentous & 11 & 10.7 \\
No growth & 3 & 2.9 \\
Total & 103 & 100 \\
\hline
\end{tabular}

$\mathrm{F}=$ frequency.

Various microbial species were identified in the 162 isolates from the cockroaches collected at a large hospital in the midwestern region of Brazil (Table 4).

Two major groups of bacteria with great epidemiological significance for nosocomial infections were isolated, enterobacteria and coagulase-negative staphylococci. Among the enterobacteria, Klebsiella pneumoniae was the most prevalent; it was isolated from $18 \%$ of the cockroaches Enterobacter aerogenes from 14.5\%, Serratia marcescens from $13 \%$, Hafinia alvei from 12\%, Enterobacter cloacae and Enterobacter gergoveae from 9\%. Coagulase-negative
Staphylococci (CNS) were found in $18 \%$ of the isolates. All of these bacteria can be involved with disease breakouts and nosocomial infection, especially in intensive care units (ICU), medical clinics, surgical and orthopedic units [11-14].

It is known that, among the enterobacteria isolated from the tips of vascular catheters, hemocultures and other biological materials from infected onco-hematological patients, $K$. pneumoniae and E. coli predominate with $18 \%$ and $4.4 \%$, respectively [20,21].

These results coincide with those found by Ribas, who found a predominance of $K$. pneumoniae and $E$. coli in bacteremias in patients approximately 61 years old who had been hospitalized for a period of seven days. As $K$. pneumoniae was isolated in $12.7 \%$ of the cockroaches, we presume that this insect is disseminating this bacteria in the hospital environment [22].

Table 4. Frequency of the types of microorganisms isolated from Periplaneta americana collected at a large hospital in Goiânia, Brazil in 2002

\begin{tabular}{lrr}
\hline Microorganism & F & \% \\
\hline Coagulase-negative staphylococci & 32 & 25.4 \\
Klebsiella pneumoniae & 16 & 12.7 \\
Enterobacter aerogenes & 13 & 10.3 \\
Serratia marcescens & 12 & 9.5 \\
Hafnia alvei & 11 & 8.7 \\
Enterobacter cloacae & 8 & 6.3 \\
Enterobacter gergoviae & 8 & 6.34 \\
Serratia sp. & 6 & 4.8 \\
Other Gram-negative bacilli & 20 & 15.9 \\
Total & 126 & 100 \\
\hline
\end{tabular}

$\mathrm{F}=$ frequency

Profile of antimicrobial susceptibility. The resistance of microorganisms to antimicrobials dates back to the discovery of microbes and to the development of the first antibiotics, which was a time when the introduction of antimicrobial therapy was regarded as the solution to all diseases caused by infections $[11,12]$. The broad and indiscriminate use of antibiotics has led to the selection of resistant strains. However, their empirical utilization and the lack of institutional standardization policies, as well as the lack of pre-established criteria for therapeutic acquisition and prescription, among other factors, has resulted in selective pressure, selecting for multiresistant microbrial strains that have caused difficulties for the treatment of patients and have generated irreparable loss to institutions [11-14].

Enterobacteria and coagulase-negative staphylococci isolated from cockroaches were tested for antimicrobial susceptibility (Table 5).

Table 5 shows the distribution and frequency of enterobacteria in relation to antimicrobial susceptibility; $96.8 \%$ were found to be resistant to gentamicin; $84 \%$ to ampicillin; 
$75.3 \%$ to caphalothin; $66.7 \%$ to sulbactam/ampicillin; $50 \%$ to aztreonam and $30 \%$ to chloramphenicol. However, $100 \%$ were sensitive to cefepime and ciprofloxacin; $83 \%$ to sulfazotrin; $70 \%$ to chloramphenicol; $60.2 \%$ to ceftriaxon; and $33.3 \%$ to sulbactam/ampicillin.

Table 5. Distribution of the frequency and percent of enterobacteria isolated from Periplaneta americana in a large public hospital according to antimicrobial susceptibility in Goiânia, Brazil in 2002

\begin{tabular}{lcccccccc}
\hline $\begin{array}{l}\text { Susceptibility } \\
\text { antimicrobial }\end{array}$ & $\mathbf{S}$ & $\mathbf{\%}$ & $\mathbf{F}$ & $\mathbf{\%}$ & $\mathbf{F}$ & $\boldsymbol{\%}$ & $\mathbf{F}$ & $\boldsymbol{\%}$ \\
\hline Ampicillin & 15 & 16.10 & 06 & 6.50 & 72 & 77.40 & 93 & 100 \\
Ampicillin/ & 02 & 33.30 & - & - & 04 & 66.70 & 06 & 100 \\
$\quad$ sulbactam & & & & & & & & \\
Aztreonam & - & - & 03 & 50.0 & 03 & 50.00 & 06 & 100 \\
Caphalothin & 23 & 24.70 & 05 & 5.40 & 65 & 69.90 & 93 & 100 \\
Cefepime & 06 & 100.0 & - & - & - & - & 06 & 100 \\
Ceftriaxon & 56 & 60.20 & 30 & 32.30 & 07 & 7.50 & 93 & 100 \\
Ciprofloxacin & 06 & 100.0 & - & - & - & - & 06 & 100 \\
Chloramphenicol & 65 & 69.90 & 02 & 2.20 & 26 & 27.90 & 93 & 100 \\
Gentamicin & 03 & 3.20 & 15 & 16.10 & 75 & 80.70 & 93 & 100 \\
Sulfazotrin & 77 & 82.80 & 01 & 1.10 & 15 & 16.10 & 93 & 100 \\
\hline
\end{tabular}

$\mathrm{F}=$ frequency $\mathrm{S}=$ sensitive $\mathrm{I}=$ intermediate $\mathrm{R}=$ resistant; $\mathrm{T}=$ total number of enterobacteria strains submitted to the antibiogram.

The profile of susceptibility to sulfazotrin of the enterobacteria strains evaluated in this study was excellent ( $83 \%$ sensitivity). These results can be associated with the efficacy of sulfas for the control of enterobacteria. Ciprofloxacin is one of the most powerful quinolones against Gram-negative bacteria, including methicillin-resistant and anaerobic staphylococci [12]. There was $100 \%$ sensitivity of enterobacteria to this drug.

Cefepime, a fourth-generation cefalosporin, acts upon Gram-negative bacteria and also acts against Gram-positive enterobacteria [11,12]. All the species submitted to the susceptibility tests were sensitive to cefepime.

The results are in accordance with those found by Bradios, who found Enterobacter sp. in $83.7 \%$, E. cloacae in $11.7 \%$ and E. aerogenes in $2.3 \%$ of 1,011 clinical isolates [23]. These species showed a sensitivity of $95 \%$ to imipenem and $93 \%$ to cefepime; however, when evaluating the results of antibiograms of 255 ICU patients, Azevedo and Savassi observed that, among 1,132 isolated microorganisms, 59.6\% were CNS, $18.7 \%$ were Klebsiella sp. and $11.9 \%$ were Enterobacter sp. [24]. The enterobacteria were resistant to cefepime and ceftriaxon.

Sulbactam/ampicillin is clinically useful due to the inhibition of beta lactamase, which is effective in the treatment of serious infections, such as respiratory, urinary, gynecological, intra-abdominal infections and septicemia triggered by beta-lactamase-producing organisms. Sulbactam is associated with the following antibiotics: ampicillin, amoxacilin and cefaloperazon $[11,12]$. The results our study confirm those described in the literature, since the resistance rates of microorganisms submitted to sulbactam/ampicillin susceptibility tests reached $67 \%$.

Chloramphenicol is an antibiotic with a broad action spectrum. It acts against both Gram-positive bacilli (GPB) and Gram-negative bacilli (GNB), among others, and resistance against it is acquired through plasmid transfer between enterobacteria, staphylococci, and others [12]. However, we found that $70 \%$ of the enterobacteria isolated from cockroaches were sensitive to chloramphenicol.

Ceftriaxon is a third-generation semi-synthetic cefalosporin that acts upon GPB and BGN and is not affected by betalactamase. It can act on BGN that are resistant to first- and second-generation cefalosporins; however, there may be resistance in situations involving bacterial strains that are resistant to this substance as a result of the non-hydrolytic barrier, impermeability mechanisms, modification of their action receptor or by penicillin-fixing proteins [12,25]. The enterobacteria isolated from Periplaneta americana were sensitive to ceftriaxon.

Caphalothin is a first-generation cefalosporin antibiotic that is characterized by its bactericidal activity on GPB and GNB, by resistance to staphylococci beta-lactamases and sensitivity to the beta-lactamases produced by GNB [12]. However, the results of tests of susceptibility to that antibiotic are in agreement with most of the results presented in the literature, since $75 \%$ of the microorganisms isolated from the cockroaches were resistant to caphalothin. We observed that various microorganisms, such as Enterobacter (55\%), Serratia sp. (26\%), Citrobacter sp. (14.5\%) and Providencia sp. $(4.5 \%)$ were resistant to first- and second generation cefalosporins [26].

Gentamicin is a broad-spectrum antibiotic that acts against GPB and GNB. Its main activity is against the latter, particularly enterobacteria [12]. However, the enterobacteria isolated from the the cockroaches were relatively resistant to gentamicin: $21.5 \%$ for Klebsiella pneumoniae, $14 \%$ for Enterobacter aerogenes, $13 \%$ for Serratia marcescens and Hafnia alvei; $6.5 \%$, for Enterobacter cloacae and $5.5 \%$ for Serratia sp. and E. gergoveae. Resistance can be due to the inadequate use of antimicrobials.

Aztreonam, an antibiotic that is active against GNB and enterobacteria, presents exceptional resistance to inactivation by beta-lactamases, and its action takes place through interference in the bacterial cell wall synthesis [12]. Enterobacteria strains submitted to tests of susceptibility to aztreonam were found to be resistant.

Resistance profiles were investigated in microorganisms isolated from 635 hemoculture samples from neonates; $65.5 \%$ were Gram-negative, among which $35.9 \%$ were $K$. pneumoniae, and $13.4 \%$ S. marcescens [27]. Among the Gram-positive microorganisms, CNS were the most frequent, accounting for 
$64.8 \%$. Gram-negative bacteria presented a mean frequency of resistance of $81.6 \%$ to chloramphenicol, $74.3 \%$ to sulphametoxazol-trimetropim, of $66 \%$ to cefalosporins, $64.7 \%$ to aminoglycosides, $52.6 \%$ to tetracyclins, $7.2 \%$ to ciprofloxacin and $2.6 \%$ to imipenem. Among the Gram-positive bacteria, $63.6 \%$ multiple-resistant Staphylococcus aureus were observed.

The results of tests of susceptibility to antimicrobials of coagulase-negative staphylococci are presented in Table 6.

Table 6. Frequency distribution of the susceptibility of coagulase-negative staphylococci isolated from Periplaneta americana at a large hospital In Goiânia, Brazil in 2002

\begin{tabular}{lcccc}
\hline Antimicrobial & S & I & R & Total \\
\hline Ampicillin & 08 & 01 & 04 & 13 \\
Cefalexin & 06 & 03 & 04 & 13 \\
Cefepime & 10 & 00 & 03 & 13 \\
Oxacillin & 05 & 03 & 05 & 13 \\
Vancomycin & 13 & 00 & 00 & 13 \\
\hline
\end{tabular}

$\mathrm{S}=$ sensitive $\mathrm{I}=$ intermediate $\mathrm{R}=$ resistant

The frequency distribution and the percent of coagulasenegative staphylococci submitted to antimicrobial tests are described in Table 7.

Table 7. Distribution of frequency (F) and percent susceptibility of coagulase-negative staphylococci isolated from Periplaneta americana in a large hospital in Goiânia, Brazil in 2002

\begin{tabular}{|c|c|c|c|c|c|c|c|c|}
\hline \multirow[t]{2}{*}{ Antimicrobial } & \multicolumn{2}{|r|}{$\mathbf{S}$} & \multicolumn{2}{|r|}{ I } & \multicolumn{2}{|r|}{$\mathbf{R}$} & \multicolumn{2}{|c|}{$\mathbf{T}$} \\
\hline & $\mathbf{F}$ & $\%$ & $\mathbf{F}$ & $\%$ & $\mathbf{F}$ & $\%$ & $\mathbf{F}$ & $\%$ \\
\hline Ampicillin & 08 & 61.50 & 01 & 07.70 & 04 & 30.80 & 13 & 100 \\
\hline Cefalexin & 06 & 46.10 & 03 & 23.10 & 04 & 30.80 & 13 & 100 \\
\hline Cefepime & 10 & 77.00 & - & - & 03 & 23.00 & 13 & 100 \\
\hline Oxacillin & 05 & 38.50 & 03 & 23.00 & 05 & 38.50 & 13 & 100 \\
\hline Vancomycin & 13 & 100.0 & - & - & - & - & 13 & 100 \\
\hline
\end{tabular}

$\mathrm{S}=$ sensitive $\mathrm{I}=$ intermediate $\mathrm{R}=$ resistant; $\mathrm{T}=$ number of $\mathrm{CNS}$ strains submitted to the antibiogram.

Among the CNS isolated in the study, $61 \%$ were oxacillin resistant. This resistance was regarded as high. All CNS were sensitive to vancomycin. Oxacilin is a semi-synthetic penicillin with betalactamic action. It acts on staphylococci, and its improper use has led to high resistance $[11,12]$.

Coagulase-negative staphylococci are among the microorganisms that are most frequently found in peritonitis patients submitted to dialytic treatment through Continuous Peritoneal Dialysis for Outpatients (CPDO). Recurrences cause the treatment to be interrupted and patients to be hospitalized, which has increased antimicrobial resistance and made treatment more costly [28,29].

Studies conducted with the purpose to isolate pathogens involved in blood infections using hemocultures of neonates showed that CNS was present in $41.6 \%$ of the 137 microorganisms that had been isolated [30].

The colonization of the insertion site of vascular catheters from swab and blood samples collected from inpatients who had been catheterized for longer than seven days and presented colony counts over $200 \mathrm{cfu} / \mathrm{cm}^{2}$ were found to have CNS with a prevalence of resistance to oxacillin [31].

Among 246 CNS strains isolated from 376 hemocultures of hospitalized children, there was a $32.5 \%$ resistance rate to oxacillin [32]. Analyzing the hemocultures of 45 neutropenic patients, there was $61 \%$ S. epidermidis and $13 \% S$. haemolyticos, among others, of which $89 \%$ were resistant to penicillin, $67 \%$ to ceftazidim, and $64 \%$ to cefotaxin and oxacillin [33].

Based on the antimicrobial resistance profile established in our study, the results of the antibiograms of the patients who had been hospitalized in our institution in the last six months were observed. We found that the most frequently used antimicrobials in the hospital during that time period were: amicacin, ampicillin, sulbactam/ampicillin, aztreonam, caphalothin, cefepime, cefotaxin, cefoxitin, ceftazidim, cefiadin, chloranmphenicol, ceftriaxon, ciprofloxacin, imipenem, levofloxacin, gentamicin, netilmicin, ofloxacin, pefloxacin, piperacillin, sulfazotrin, tetracyclin, and sulphametoxazoltrimetoprim.

Among the 24 types of antimicrobials used in the institution during that period, 10 were tested in our study, demonstrating resistance to amicacin, ampicillin, sulbactam/ ampicillin, gentamicin, caphalothin and aztreonam. These results can be correlated with the unrestricted use of such antimicrobials and associated with the profiles of inpatients, which has enabled the emergence of resistant strains. The lack of knowledge regarding hospital microbiota and the improper monitoring of antimicrobial therapeutics can lead to institutional microbial resistance, thus favoring selective pressure to develop resistant strains.

It is of utmost importance that healthcare professionals, from managers to healthcare givers, realize what the environmental requirements are, particularly those related to hygiene, cleaning, pharmacy, nutrition and dietetics services, paying special attention to the management of solid and liquid wastes.

The antimicrobial susceptibility profile of microorganisms isolated from the cockroaches at this hospital underlines the importance of developing an infra-structure that complies with site requirements, adequately monitoring the functions that are inherent to the hygiene and cleaning service and defining safe criteria with regard to the acquisition of medication, cleaning materials, and other products, controlling and optimizing food handling in the institution, standardizing the careful use of antimicrobials and the implementation of an integrated pest control program $[8,10,13,34]$.

Nosocomial infection prevention is directly related to the protection barriers between the host and the microorganism. Barriers can be physical, mechanical, or chemical. Some 
prophylactic measures are: preventing the dissemination of microorganisms from one patient to another, from the professional to the patient, and vice-versa, and from the environment to the hospital community in general $[4,35,36]$.

Healthcare managers have a fundamental role in the planning and implementation of efficient and accessible measures aiming at infection prevention. In particular, they must make viable administrative policies for vector control, hygienization and cleaning of the nosocomial environment, in addition to the controlled use of antimicrobials.

The researchers who conducted this study are aware of the fact that this is a polemic topic that involves a process of awareness development and behavioral change by health care professionals, patients and visitors. The findings point to the need for further studies to be conducted with the purpose to design, implement and evaluate strategies to control insects and rodents, and cockroaches in particular, in health care institutions as regards infection control and prevention in order to provide a biologically safe environment.

\section{Conclusions}

The incidence of enterobacteria, coagulase-negative staphylococci and fungi isolated from cockroaches in the hospital can be associated with factors such as environmental hygiene, inadequate food provision and unrestricted use of antimicrobials. It has been made evident that such factors are relevant to the morbidity-mortality of institutionalized clients that results from nosocomial infections. We think that infection control, particularly that of nosocomial infection, is closely related to an awareness development process among managers and other professionals working in health care institutions; investment in infra-structure, human resources and equipment acquisition are fundamental in order to fight against this problem that has stricken humanity over time [35,37]. Given such a viewpoint, this study brings relevant microbiological contributions to environmental sanitation related to nosocomial infection with reflection on the health care sciences, since we analyzed species of microorganisms isolated and identified from hospital cockroaches that can trigger serious infectious breakouts of undoubted epidemiological significance in healthcare institutions.

\section{References}

1. Mariconi F.A.M. Inseticidas-1 e seu emprego no combate às pragas. São Paulo: Biblioteca Rural/Livraria Nobel; 1980. p. 44-5.

2. Morel M.M.A., Bertussi Filho L.A. Resíduos de serviços de saúde. In: Rodrigues E.A.C., et al. Infecções hospitalares: prevenção e controle. São Paulo: Sarvier; 1997. p.519-34.

3. Rocha A.A. Resíduos sólidos e meio ambiente no Estado de São Paulo. São Paulo: Secretária do Meio Ambiente/Coordenadoria de educação ambiental; 1998. p. 15- 22.
4. Center for Disease Control and Prevention. Cockroaches Cucarachas. <www.cdc.gov/niosh/nasd/docs4/ txp8017.html.> Accessed: September 14, 2001.

5. Prado M., Pimenta F.C., Gir E., et al. Enterobactérias isoladas de baratas (Periplaneta americana) capturadas em um hospital brasileiro. Rev Panam Salud Publica/Pan Am J Public Health; 2002;11(2):93-7.

6. Carrera M. Entomologia para você. São Paulo(SP): Edart Livraria e Editora, 1967.

7. Costa M.J. Controle de animais sinantrópicos (Artrópodes e Roedores). In: Fernandes AT et al. Infecções hospitalares e suas interfaces na área da saúde. São Paulo: Guanabara Koogan; 2000;2:202.

8. Brasil. Ministério da Saúde. Portaria n ${ }^{\circ} 2.616$ de 12 de maio de 1998.

9. Guyader A.L., Rivault C. Microbial organisms carried by brownbanded cockoaches in relation to their satial distribution in a hospital. Epidemiol. Inf 1991;2:485-92.

10. Fernandes A.T., Fernandes M.O.V., Filho N.R. Infecções hospitalares e suas interfaces na área da saúde. São Paulo, Editora Atheneu; 2000. 1:3-22, 43-71, 91-125.

11. Ribeiro Filho N. agentes Antimicrobianos. In: Fernandes AT et al. Infecções hospitalares e suas interfaces na área da saúde. São Paulo: Guanabara Koogan; 2000. 1:1485-534.

12. Tavares W. Manual de antibióticos e quimioterápicos. São Paulo, Atheneu; 2001. 792 p.

13. Rodrigues E.A.C., Mendonça J.S., Amarante J.M.P., et al. Infecções hospitalares: prevenção e controle. São Paulo:Sarvier; 1997. p.12,20,25-6.

14. Grinbaum R.S. UTI: controle de infecção é um grande desafio. Meio de Cultura. São Paulo: Eurofarma, 2001; 16:3-7.

15. Fotedar R., Shriniwas U.B., Verna A. Cockoaches (Blattella germanica) carries of microorganisms of medical importance in hospitals. Epidemiol. Infect 1991;107:181- 7.

16. Westergreen G., Krasse B. Evolution of a micromethod for determination of Streptococcus mutans and lactobacillus infection. J Clin Microbiol 1978;7:82-3.

17. Koneman E.W., Allen S.D., Dowell V.R. Jr., Sommers H.M. Diagnóstico Microbiológico, texto atlas colorido; São Paulo: Panamericana; 1993. p. 83-128.

18. National Committee for Clinical Laboratory Standards (NCCLS) - Performance standards for antimicrobial susceptibility testing; Eleventh informational supplement M100-S11. Wayne, PA, 2001. NCCLS, 2000.

19. Wagner S.J., Friedman L.I., Dood R.Y. Transfusion associated bacterial sepsis. Clin Microbiol Rev 1994;7:290-320.

20. Ueda S.M.Y., Fernandes A.T. Fungos. In: Fernandes A.T., et al. Infecções hospitalares e suas interfaces na área da saúde. São Paulo: Guanabara Koogan; 2000; 1:418-52.

21. Gomes A.C.L.F., Martinez R. Detecção de enterobactérias produtoras de beta-lactamases de espectro estendido (ESBL) em amostras de sangue, cateter e outros materiais biológicos de pacientes do Hospital das Clínicas de Ribeirão Preto (HCPMRP). Anais do $21^{\circ}$ Congresso Brasileiro de Microbiologia; Out. 21-25; Foz do Iguaçu (PR), 2001.p.75.

22. Ribas R.M., Brito D.V.D., Freitas C., et al. Fatores de risco e fenótipos de resistência de bactérias Gram-negativas associadas a bacteremias hospitalares e comunitárias no HCUFU. Anais do $21^{\circ}$ Congresso Brasileiro de Microbiologia; Out. 21-25; Foz do Iguaçu (PR), 2001.p.142. 
23. Braoios A., Almeida M.C., Pompei A.C.S.C., Bellini C.A., et al. Incidência e suscetibilidade de Enterobacter $s p$ isolados em um Hospital Universitário. Anais do $21^{\circ}$ Congresso Brasileiro de Microbiologia; Out. 21-25; Foz do Iguaçu (PR), 2001.p.154.

24. Azevedo F.M., Savassi L.C.M. Avaliação da distribuição de freqüência e do perfil de sensibilidade dos principais microrganismos isolados no CTI do Hospital das Clínicas da UFMG nos anos de 1998 e 1999. Anais do $3^{\circ}$ Congresso Pan-Anamericano, $7^{\circ}$ Congresso Brasileiro e $1^{\circ}$ Congresso Odontologia de Minas Gerais em Controle de Infecção e Epidemiologia Hospitalar; Nov. 10-14; Belo Horizonte(MG), 2000. p. 171.

25. Yehuda C., Castro J., Eliopoulos G.M., Samore M.H. Clinical isolation and patterns of and superinfection with 10 nosocomial pathogens after treatment with ceftriaxone versus ampicillin-sulbactam. Antimicrobial agents and chemotherapy. Am Soc Microbiol 2001;45(1):275-9.

26. Miyashita D., Nunes V.S., Juares A.J.C., et al. Perfil de suscetibilidade de bactérias do grupo Citrobacter, Enterobacter, Serratia e Providência (CESP) frente aos beta-lactâmicos. Anais do $21^{\circ}$ Congresso Brasileiro de Microbiologia; Out. 21-25; Foz do Iguaçu (PR), 2001. p.72.

27. Moraes B.A., Loureiro M.M., Quadra M.R.R., et al. Perfil de resistência bacteriana em hemoculturas positivas de recémnatos em uma maternidade do Rio de Janeiro no Período de 1997 a 2001. Anais do $21^{\circ}$ Congresso Brasileiro de Microbiologia; Out. 21-25; Foz do Iguaçu (PR), 2001.p.158.

28. Barretti P., Cunha M.L.R.S., Montelli A.C., et al. Estudo da patogenicidade de Estafilococos Coagulase Negativo isolado de pacientes em CAPD com peritonite. Anais do $21^{\circ}$ Congresso Brasileiro de Microbiologia; Out. 21-25; Foz do Iguaçu (PR), 2001.p.130.

29. Montelli A.C., Cunha M.L.S., Caramori J.C.T., et al. Contribuições microbiológicas e clínicas para abordagem de pacientes com peritonite por Estafilococos Coagulase Negativo em CAPD. Anais do $21^{\circ}$ Congresso Brasileiro de Microbiologia; Out. 21-25; Foz do Iguaçu (PR), 2001. p.154.
30. Sarquis M.G. Isolados de hemoculturas em CTI neonatal de hospital geral. Anais do $3^{\circ}$ Congresso Pan-Anamericano, $7^{\circ}$ Congresso Brasileiro e $1^{\circ}$ Congresso Odontologia de Minas Gerais em Controle de Infecção e Epidemiologia Hospitalar; Nov. 10-14; Belo Horizonte(MG), 2000. p. 170

31. Sadoyama G. Fatores de risco para a colonização cutânea no sítio de inserção de cateter vascular central (CVC) Anais do $3^{\circ}$ Congresso Pan-Anamericano, $7^{\circ}$ Congresso Brasileiro e $1^{\circ}$ Congresso Odontologia de Minas Gerais em Controle de Infecção e Epidemiologia Hospitalar; Nov. 10-14; Belo Horizonte(MG), 2000. p.62

32. Menezes e Silva C.H.P., Salvino C.R. Oxacilina Resistent Staphylococci isolated from hospitalized patients. Anais do $21^{\circ}$ Congresso Brasileiro de Microbiologia; Out. 2125; Foz do Iguaçu (PR), 2001.p.114.

33. Mitsugui C.S., Santin M.R., Mazzer C., Herrero F. Ocorrência de Estafilococos Coagulase Negativo Produtor de Enterotoxina e Toxinas TSST-1 em hemoculturas de pacientes neutropênicos. Anais do $21^{\circ}$ Congresso Brasileiro de Microbiologia; Out. 21-25; Foz do Iguaçu (PR), 2001. p.77.

34. Panizzi A.R., Parra J.R.P. Ecologia nutricional de insetos e suas implicações no manejo de pragas. São Paulo (SP), 1991.

35. Prado M.A. Bacterias isoladas de Periplaneta americana de um hospital público de grande porte da região centrooeste. [M.Sc. Thesis]. Ribeirão Preto (SP): Escola de Enfermagem de Ribeirão Preto/USP; 2002.

36. Dias Ângelo D.A. A manutenção de um ambiente hospitalar biologicamente seguro: avaliação microbiológica dos leitos de um hospital geral antes e depois de sua limpeza terminal. [Ph.D. thesis]. Ribeirão Preto (SP): Escola de Enfermagem de Ribeirão Preto/USP; 1998.

37. Tipple A.F.V. As interfaces do controle de infecção hospitalar em uma unidade de ensino odontológico. [Ph.D. thesis]. Ribeirão Preto (SP): Escola de Enfermagem de Ribeirão Preto/USP; 2000. 